\title{
New insights into the mechanisms of venous thrombosis
}

\author{
Nigel Mackman \\ Division of Hematology/Oncology, Department of Medicine, UNC McAllister Heart Institute, \\ University of North Carolina at Chapel Hill, Chapel Hill, North Carolina, USA.
}

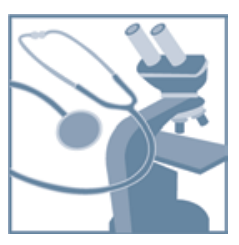

\begin{abstract}
Venous thrombosis is a leading cause of morbidity and mortality in industrialized countries, especially in the elderly. Many risk factors have been identified for venous thrombosis that alter blood flow, activate the endothelium, and increase blood coagulation. However, the precise mechanisms that trigger clotting in large veins have not been fully elucidated. The most common site for initiation of the thrombus appears to be the valve pocket sinus, due to its tendency to become hypoxic. Activation of endothelial cells by hypoxia or possibly inflammatory stimuli would lead to surface expression of adhesion receptors that facilitate the binding of circulating leukocytes and microvesicles. Subsequent activation of the leukocytes induces expression of the potent procoagulant protein tissue factor that triggers thrombosis. Understanding the mechanisms of venous
\end{abstract} thrombosis may lead to the development of new treatments.

\section{Introduction}

Thrombosis describes the formation of a clot within a blood vessel that reduces blood flow and may cause infarction of tissues supplied by that vessel. The most common forms of occlusive thrombosis occur in arteries and lead to myocardial infarction and stroke (1). Deep vein thrombosis (DVT) mostly occurs in the legs and is associated with pulmonary embolism (PE); collectively, these are termed venous thromboembolism (VTE) (2). The incidence of VTE in industrialized countries is $1-3$ individuals per 1,000 per year (3-8). Importantly, there is a dramatic increase in the risk of VTE above the age of 50, and it reaches as high as 1 in every 100 individuals annually (3). These alarming statistics led the US Senate to designate March as "DVT Awareness Month" in 2005 and the Surgeon General's call to action to prevent DVT and PE in 2008.

There are many genetic and acquired risk factors that are associated with VTE and recurrent VTE (reviewed in refs. 8-11). Strong genetic risk factors that lead to a hypercoagulable state include deficiencies in the anticoagulants antithrombin, protein $\mathrm{C}$, and protein S. Moderate genetic risk factors include factor $\mathrm{V}(\mathrm{FV})$ Leiden, prothrombin G20210A, fibrinogen C10034T and nontype $\mathrm{O}$ blood. FV Leiden is present in approximately $5 \%$ of people of mixed European descent and is a variant of FV that is resistant to inactivation by activated protein C. Prothrombin G20210A is single nucleotide polymorphism in the $3^{\prime}$ untranslated region of the prothrombin gene that leads to increased expression. Fibrinogen $\mathrm{C} 10034 \mathrm{~T}$ is a fibrinogen gamma-chain gene variant that leads to reduced levels of the alternatively spliced form of the fibrinogen gamma-chain that is associated with increased venous thrombosis (8). Finally, individuals with non-type O blood have increased clearance of von Willebrand factor (vWF). Since FVIII circulates in plasma bound to $\mathrm{vWF}$, a reduction in plasma $\mathrm{vWF}$ is also associated with reduced levels of FVIII.

Acquired risk factors include age, surgery, obesity, cancer, pregnancy, hormone-based contraceptives, hormone replacement, antiphospholipid syndrome, acute infection, immobilization,

Conflict of interest: The author has declared that no conflict of interest exists. Citation for this article: J Clin Invest. 2012;122(7):2331-2336. doi:10.1172/JCI60229. paralysis, long-haul travel, smoking, hospitalization, reduced fibrinolysis, and acquired thrombophilia (increased levels of procoagulant factors and/or decreased levels of anticoagulant factors) (12-30). Obesity has a high prevalence in the US and Western countries $(15,25,29)$, and one study showed that obesity (body mass index $\geq 30 \mathrm{~kg} / \mathrm{m}^{2}$ ) increased the risk of thrombosis 2 fold (25). Another study analyzed the risk associated with oral contraceptives with or without FV Leiden and found that the incidence of thrombosis was increased 4 fold in individuals taking hormone contraceptives, 7 fold in those with FV Leiden, and 36 fold in individuals with both risk factors (24). This study demonstrated remarkable synergy of these risk factors. A VTE risk scoring model has been established for ambulatory patients with cancer based on 5 parameters (tumor site, leukocyte count, platelet count, body mass index, and either low hemoglobin and/or use of erythropoiesis-stimulating agents) (31). Symptomatic VTE was observed in $0.6 \%$ of patients with a score of 0 compared with $6.9 \%$ of patients with a score of 3 or higher. A recent study extended this scoring system to include the biomarkers D-dimer and P-selectin and found that patients with the highest score had a cumulative VTE probability after 6 months of 35\% compared with a probability of $1 \%$ for those patients with the lowest score (32).

\section{Clot formation}

A blood clot contains a mixture of platelets and fibrin and in some cases red blood cells $(1,33)$. Importantly, the etiologies of arterial and venous clots are very different (1). Arterial clots are formed under high shear stress, typically after rupture of an atherosclerotic plaque or other damage to the blood vessel wall (34-36). They are platelet-rich (so called "white clots") and are generally treated with antiplatelet drugs. In contrast, venous clots form under lower shear stress on the surface of a largely intact endothelium (36-39). They are fibrin-rich (so called "red clots" because they also contain red blood cells) and are treated with anticoagulant drugs.

The blood coagulation cascade can be divided into three parts: the extrinsic, intrinsic, and common pathways (Figure 1 and reviewed in refs. 39-42). Under pathological conditions, tissue 


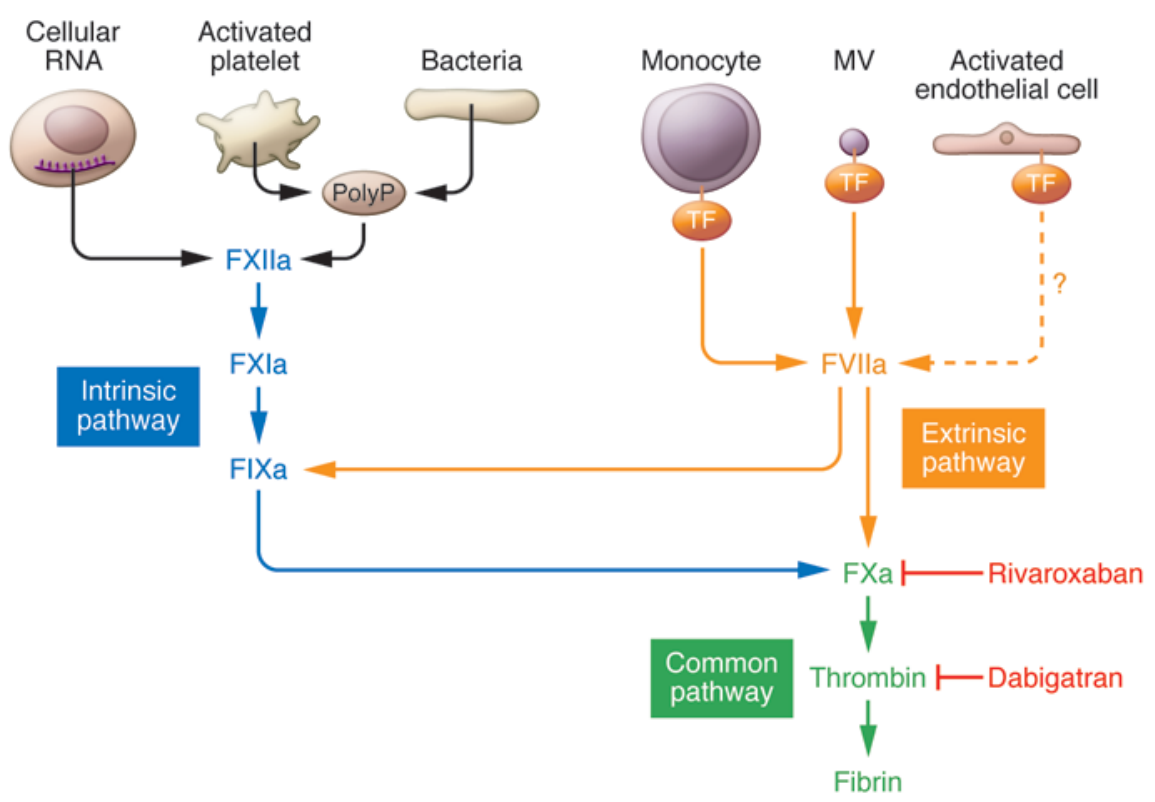

\section{Figure 1}

Activation of the coagulation cascade. The coagulation cascade can be divided into the extrinsic (TF, FVIIa), intrinsic (FXIla, FXla, FIXa), and common (FXa and thrombin) pathways. The FIXa and FXa cofactors (FVIIla and FVa, respectively) are not shown. Pathological activation of the extrinsic pathway is via TF expression in activated monocytes, monocyte-derived MVs, and possibly activated endothelial cells. Cellular RNA and polyphosphate (PolyP) released from activated platelets or bacteria activate FXIla in the intrinsic pathway. The two new FDA-approved anticoagulant drugs rivaroxaban and dabigatran inhibit $\mathrm{FXa}$ and thrombin, respectively. factor (TF) is expressed on circulating leukocytes and possibly activated endothelial cells (40). In addition, TF is present on microvesicles (MVs), which are small membrane vesicles released from activated cells (43-45). These intravascular sources of TF may trigger the formation of venous clots. Recent studies have shown that FXII can be activated by extracellular RNA and polyphosphates and this activation of the intrinsic pathway may also contribute to venous thrombosis (46-49).

The coagulation cascade is regulated at several levels by different anticoagulant pathways (50). TF pathway inhibitor blocks the TF/FVIIa complex, whereas antithrombin inhibits all coagulation proteases, including thrombin $(51,52)$. Binding of thrombin to thrombomodulin on the surface of endothelial cells changes its substrate specificity from fibrinogen to protein $\mathrm{C}$ and therefore plays a key role in shutting down the clotting cascade (53). Binding of protein $C$ to the endothelial cell protein $C$ receptor enhances its conversion to activated protein $\mathrm{C}$, which in association with its cofactor protein $S$, cleaves and inactivates both FVa and FVIIIa (54). Importantly, loss of a single anticoagulant pathway leads to embryonic lethality (50). One explanation for this observation is that different tissues use distinct anticoagulant pathways to regulate clotting $(50,55)$. Clots in blood vessels are removed by proteolytic digestion of fibrin by plasmin (56). Levels of plasmin are regulated by plasminogen activators and inhibitors, particularly plasminogen activator inhibitor 1 (PAI-1) (57). This explains why elevated levels of PAI-1 are associated with thrombosis (8).

Traditionally, VTE is treated with anticoagulant drugs to prevent growth and embolization of the thrombus. Patients initially receive some form of injectable heparin, which acts rapidly, followed by a more prolonged course of an oral vitamin $\mathrm{K}$ antagonist (58-60). These drugs have been used for over 50 years. Heparins inhibit FXa and thrombin in an antithrombin-dependent manner, whereas vitamin $\mathrm{K}$ antagonists reduce the activity of vitamin $\mathrm{K}$ dependent proteins, including FVIIa, FIXa, FXa, and thrombin. The limitations of these drugs have fueled the search for new anticoagulant therapies. Over the past 5 years, several new oral drugs have been developed, the two most advanced of which are rivar- oxaban (Xarelto), which selectively inhibits FXa, and dabigatran etexilate (Pradaxa), which selectively inhibits thrombin (Figure 1 and refs. 61-65). Rivaroxaban was shown to be superior to the low-molecular-weight heparin enoxaparin in reducing VTE in four clinical trials involving total knee and hip replacement (65); in 2011, it was approved by the FDA for thrombosis prophylaxis to reduce the risk of DVT and PE following knee and hip replacement surgery. Dabigatran showed non-inferiority to enoxaparin in 3 out of 4 trials for high-risk orthopedic patients but has not been approved for thrombosis prophylaxis in this population (60).

\section{Mechanisms of venous thrombosis}

In the 19th century, the noted physician Virchow proposed a triad of physiological alterations that increase the risk of VTE: changes in blood flow, in the blood itself, and in the endothelial cells lining the blood vessel (66).

\section{Reduced blood flow and stasis}

Reduced blood flow and stasis allow the accumulation of procoagulant proteases, such as thrombin, that may overcome the local anticoagulant pathways and induce thrombosis. Reduced blood flow and stasis may explain the increased rate of VTE associated with surgery, hospitalization, paralysis, long-haul travel, cancer, obesity, age, and pregnancy $(15,18-20,25,28-30)$. Interestingly, there is a left-sided predominance of proximal thrombosis during pregnancy that is thought to be due to an acquired compression of the left common iliac vein by the presence of the fetus (67). Similarly, individuals with May-Thurner syndrome suffer from compression of left common iliac vein that increases the risk of DVT (68).

Recently, investigators have developed a new mouse model of venous thrombosis that involves stenosis rather than complete ligation of the inferior vena cava (69-71). In this model, the lumen of the vessel is reduced by $80 \%-90 \%$, but the procedure does not denude the endothelium; however, the endothelium is activated and releases vWF and P-selectin from Weibel-Palade bodies that capture leukocytes and platelets $(69,70)$. P-selectin glycoprotein ligand-1 (PSGL-1) that is expressed on leukocytes binds to P-selec- 


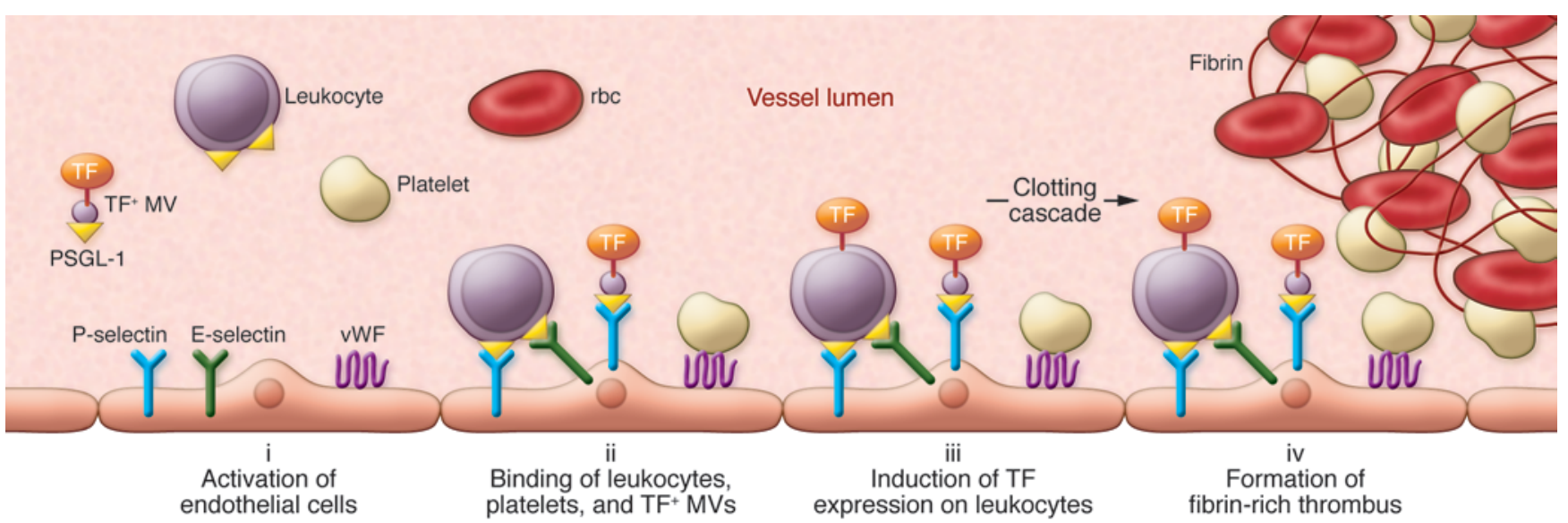

Figure 2

Proposed mechanisms for venous thrombosis. My group proposed that formation of a venous thrombosis can be divided into distinct steps. First, the endothelium is activated by hypoxia and/or inflammatory mediators and expresses the adhesion proteins P-selectin, E-selectin, and vWF. Second, circulating leukocytes, platelets, and $\mathrm{TF}^{+} \mathrm{MVs}$ bind to the activated endothelium. Third, the bound leukocytes become activated and express TF. The local activation of the coagulation cascade overwhelms the protective anticoagulant pathways and triggers thrombosis. The fibrin-rich clot also contains platelets and red blood cells.

tin on the endothelium, whereas GP1b $\alpha$ on the surface of platelets interacts with vWF $(72,73)$. In humans, the most likely site of thrombus initiation is the valve pocket sinus due to its vortical blood flow and low oxygen tension (74). It is proposed that small thrombi formed within the valve pocket grow slowly over days or weeks and extend along the inside of the vein wall and may eventually occlude the blood vessel.

\section{Procoagulant changes in the blood}

Thrombophilia describes a disorder in which the blood has a tendency to clot. Thrombophilia can be caused by increases in procoagulant proteins, the presence of variant clotting proteins that are more procoagulant, decreases in anticoagulant proteins, and/ or decreased fibrinolysis. In addition to the genetic risk factors described above, age, major surgery, cancer, pregnancy, hormone contraceptives, and obesity also confer susceptibility $(3,7,13-16$, 19-23, 25). Pregnancy produces a transient hormone-induced hypercoagulable state that probably evolved to protect women from hemorrhage at childbirth or in the event of miscarriage (20). During a normal pregnancy, levels of FVII, FVIII, FX, fibrinogen, vWF, and PAI-1 are increased and do not return to baseline until 8 weeks postpartum (21). Similarly, one study analyzed the use of oral hormone contraceptives and found increased levels of FVII, FVIII, FX, prothrombin and fibrinogen (23). Obese individuals have elevated levels of FVIII, FIX, and PAI-1 that likely contribute to the increased risk of VTE (29). Interestingly, monocyte TF expression was found to be increased 1 day after surgery to remove tumors (17). Similarly, TF expression on peripheral blood mononuclear cells has been shown to be increased 1 day after total knee arthroplasty (18). Levels of FVIII and fibrinogen were also increased 2-3 days after surgery (17), which appears to be secondary to inflammation. Importantly, these procoagulant changes in the blood preceded the peak of VTE that was observed 7 days after surgery (19).

\section{Activation of the endothelium}

The endothelial lining of blood vessels plays a critical role in preventing thrombosis by providing a surface that prevents attachment of cells and proteins required for clotting (75). An intact and healthy endothelium expresses various anticoagulants, such as TF pathway inhibitor, thrombomodulin, endothelial protein $\mathrm{C}$ receptor, and heparin-like proteoglycans (76). In addition, endothelial cells express the ectonucleotidase CD39/NTPDase1, which metabolizes the platelet agonist ADP. Finally, endothelial cells release the platelet inhibitors nitric oxide and prostacyclin $(75,77,78)$. However, activated endothelial cells downregulate expression of the anticoagulant protein thrombomodulin and upregulate expression of the procoagulant protein TF (79). Activation also leads to the expression of various adhesion molecules on the surface of the endothelium, such as P-selectin, E-selectin, and vWF, that capture leukocytes, platelets, and MVs $(80,81)$. Hypoxia has been shown to promote the release of vWF from Weibel-Palade bodies in endothelial cells (82).

\section{Valve pockets as a site of thrombus initiation}

Blood is returned from the venous system of the lower limbs to the heart by the calf muscles in the legs acting as pumps. In addition, valves in the large veins prevent reflux of the blood. However, the valve sinus is prone to thrombosis because of the irregular patterns of blood flow and the potential for a low oxygen tension, especially during immobilization or long-haul travel (74). Experimental stasis has been shown to result in a significant decline in oxygen tension in the sinus (83). Interestingly, the number of valves in individuals can vary, and those with more valves have a higher frequency of DVT (84). Finally, studies that analyzed non-trauma-related venous thrombi by autopsy and phlebography concluded that they originated in the valves and sinuses of the calf veins (74). To protect against thrombosis, endothelial cells lining the valve sinus express higher levels of the anticoagulant proteins thrombomodulin and endothelial cell protein $\mathrm{C}$ receptor and lower levels of $\mathrm{vWF}$ compared with those of venous endothelial cells (85). My group believes that this protective pathway becomes overwhelmed under pathological conditions.

\section{TF as a trigger for venous thrombosis}

At present, the triggers for venous thrombosis are unknown. However, it is tempting to speculate that the potent procoagulant TF 
plays a key role in some forms of VTE because under pathological conditions it is present on circulating monocytes, MVs, and possibly activated endothelium (40). Activated monocytes and tumor cells are the primary sources of TF-positive MVs in the circulation (43). One may propose that the first step in venous thrombosis is activation of the endothelium and expression of the adhesion receptors P-selectin and E-selectin as well as vWF (Figure 2). The activated endothelium then captures circulating leukocytes, TFpositive MVs, and platelets. Finally, induction of TF expressed by the bound leukocytes together with TF on MVs triggers thrombosis. This hypothesized sequence of events is supported by recent studies using a mouse inferior cava stenosis model (70). It was found that a genetic deficiency of TF in either hematopoietic cells or myeloid cells dramatically reduced venous thrombosis, which indicates that TF expression by leukocytes and possibly leukocytederived MVs initiated thrombosis in this model (70). Monocytes - and to a lesser extent neutrophils - in the thrombus expressed TF. This study also demonstrated a role for FXII and platelets in the propagation of the thrombus (70).

Importantly, major surgery is associated with an induction of TF expression by circulating monocytes (18). In addition, studies have shown that patients with cancer and mice containing tumors have high levels of tumor-derived, TF-positive MVs (86-91). One study demonstrated binding of tumor-derived MVs to an injured blood vessel and increased thrombosis in mice with tumors (92). In addition, levels of TF-positive MVs increased prior to VTE in two patients with pancreatic cancer in a small prospective study (93). However, TF is not the only factor that may trigger thrombosis; recent studies have also shown roles for vWF, platelets, extracellular chromatin from neutrophils, and even red blood cells in venous thrombosis in animal models (Figure 2 and refs. 69, 70, 94-96).

\section{Receptor-mediated binding of leukocytes and MVs to activated endothelium}

P-selectin appears to be a key endothelial cell receptor that captures circulating leukocytes and leukocyte-derived MVs expressing PSGL-1 (Figure 2) (72). In a mouse microvascular thrombosis model, docking of leukocyte-derived MVs to the site of thrombus was shown to require P-selectin, and thrombosis was reduced in mice deficient in either P-selectin or PSGL-1 $(33,97)$. Hematopoietic cell-derived, TF-positive MVs have been shown to play an important role in this microvascular thrombosis model (98). Importantly, inhibition of platelet P-selectin also blocked the recruitment of leukocytes and reduced fibrin deposition in a baboon model of thrombosis (99). More recently, it was shown that an oral P-selectin inhibitor reduced thrombosis in a baboon stasis model (100). Inhibition of P-selectin also reduced thrombosis in tumor-bearing mice (93). A pan-selectin inhibitor that has primary activity against E-selectin reduced thrombosis in an electrolytic inferior vena cava mouse model (101). In addition, neutrophils promote thrombosis by releasing serine proteases that inactivate the anticoagulant TF pathway inhibitor (102). These studies suggest that blocking the binding of leukocytes and MVs to the activated endothelium may represent a novel strategy to reduce VTE. However, it is important to note that leukocytes also play a role in the resolution of venous thrombi, which may limit this therapeutic approach to prevention rather than treatment of venous thrombosis $(103,104)$.

\section{Statins and VTE}

Statins are commonly used to treat hyperlipidemic patients and reduce the incidence of arterial thrombosis. Interestingly, recent studies found that statins also reduce VTE (105-108). A metaanalysis of 8 observational studies concluded that statins reduce the risk of VTE but cautioned that additional randomized controlled trials should be performed (109). One study randomized a group of over 17,000 healthy men and women with normal lowdensity lipoprotein cholesterol levels but high inflammation and treated them with rosuvastatin or placebo (110). The statin group exhibited a $43 \%$ reduction in the rate of VTE compared with that of the control group. At present, the mechanism by which statins reduce VTE is unclear, but the authors speculated that one mechanism may be the reduction of monocyte TF expression. Indeed, statins have been shown to inhibit TF expression in monocytes in vitro and in vivo (111-115). My group recently found that simvastatin reduced peripheral blood mononuclear cell TF expression and TF-positive MVs in hyperlipidemic monkeys, without affecting plasma cholesterol levels (115). Taken together, these results suggest that the anticoagulant activity of statins is mediated, in part, by their ability to inhibit monocyte TF expression.

\section{Conclusions and future studies}

Changes in blood flow, in the blood itself, and in the endothelium all increase the risk of VTE. New studies indicate roles for leukocytes, platelets, and MVs in the initiation and propagation of the thrombus and suggest that inhibition of the binding of leukocytes and MVs to the activated endothelium may represent a new therapeutic strategy to reduce the risk of VTE. These approaches, along further study of the antithrombotic activity of statins, suggest that improved therapies for this common disease may soon be available.

\section{Acknowledgments}

I would like to acknowledge funding from the NIH (HL 095096) as well as R. Kasthuri, A. Wolberg, and C. Mackman for helpful comments and R. Lee for help with preparing the manuscript.

Address correspondence to: Nigel Mackman, Division of Hematology/Oncology, Department of Medicine, 98 Manning Drive, University of North Carolina at Chapel Hill, Chapel Hill, North Carolina, USA. Phone: 919.843.3961; Fax: 919.966.7639; E-mail: nmackman@med.unc.edu.
1. Mackman N. Triggers, targets and treatments for thrombosis. Nature. 2008;451(7181):914-918.

2. Goldhaber SZ. Epidemiology of pulmonary embolism and deep vein thrombosis. In: Bloom $\mathrm{AL}$, et al., eds. Haemostasis and Thrombosis. 3rd ed. Edinburgh, United Kingdom: Churchill Livingstone; 1994:1327-1333.

3. Silverstein MD, Heit JA, Mohr DN, Petterson TM, O'Fallon WM, Melton LJ 3rd. Trends in the incidence of deep vein thrombosis and pulmonary embolism: a 25 -year population-based study. Arch Intern Med. 1998;158(6):585-593.

4. Kyrle PA, Eichinger S. Deep vein thrombosis. Lancet. 2005;365(9465):1163-1174.

5. Oger E. Incidence of venous thromboembolism: a community-based study in Western France. EPI-GETBP Study Group. Groupe d'Etude de la Thrombose de Bretagne Occidentale. Thromb Haemost. 2000;83(5):657-660.

6. Naess IA, Christiansen SC, Romundstad P, Cannegi- eter SC, Rosendaal FR, Hammerstrøm J. Incidence and mortality of venous thrombosis: a populationbased study. J Thromb Haemost. 2007;5(4):692-699.

7. Cushman M, et al. Deep vein thrombosis and pulmonary embolism in two cohorts: the longitudinal investigation of thromboembolism etiology. Am J Med. 2004;117(1):19-25.

8. Rosendaal FR, Reitsma PH. Genetics of venous thrombosis. J Thromb Haemost. 2009; 7(suppl 1):301-304. 
9. Reitsma PH, Versteeg HH, Middeldorp S. Mechanistic view of risk factors for venous thromboembolism. Arterioscler Thromb Vasc Biol. 2012;32(3):563-568.

10. Heit JA, et al. Relative impact of risk factors for deep vein thrombosis and pulmonary embolism: a population-based study. Arch Intern Med. 2002; 162(11):1245-1248.

11. Zhu T, Martinez I, Emmerich J. Venous thromboembolism: risk factors for recurrence. Arterioscler Thromb Vasc Biol. 2009;29(3):298-310.

12. Iorio A, et al. Risk of recurrence after a first episode of symptomatic venous thromboembolism provoked by a transient risk factor: a systematic review. Arch Intern Med. 2010;170(19):1710-1716.

13. Rosendaal FR, van Hylckama Vlieg A, Doggen CJ. Venous thrombosis in the elderly. J Thromb Haemost. 2007;5(suppl 1):310-317.

14. Lowe GD, et al. Epidemiology of coagulation factors, inhibitors and activation markers: the Third Glasgow MONICA Survey. I. Illustrative reference ranges by age, sex and hormone use. Br J Haematol. 1997;97(4):775-784.

15. Li C, Ford ES, McGuire LC, Mokdad AH. Increasing trends in waist circumference and abdominal obesity among US adults. Obesity (Silver Spring). 2007;15(1):216-224.

16. Smeeth L, Cook C, Thomas S, Hall AJ, Hubbard R, Vallance P. Risk of deep vein thrombosis and pulmonary embolism after acute infection in a community setting. Lancet. 2006;367(9516):1075-1079.

17. Osterud B, Due J Jr. Blood coagulation in patients with benign and malignant tumours before and after surgery. Special reference to thromboplastin generation in monocytes. Scand J Haematol. 1984; 32(3):258-264

18. Johnson GJ, Leis LA, Bach RR. Tissue factor activity of blood mononuclear cells is increased after total knee arthroplasty. Thromb Haemost. 2009;102(4):728-734.

19. White RH, Romano PS, Zhou H, Rodrigo J, Bargar W. Incidence and time course of thromboembolic outcomes following total hip or knee arthroplasty. Arch Intern Med. 1998;158(14):1525-1531.

20. James AH. Venous thromboembolism in pregnancy. Arterioscler Thromb Vasc Biol. 2009;29(3):326-331.

21. Bremme KA. Haemostatic changes in pregnancy. Best Pract Res Clin Haematol. 2003;16(2):153-168.

22. James AH, Jamison MG, Brancazio LR, Myers ER Venous thromboembolism during pregnancy and the postpartum period: incidence, risk factors, and mortality. Am J Obstet Gynecol. 2006;194(5):1311-1315.

23. Middeldorp S, et al. Effects on coagulation of levonorgestrel- and desogestrel-containing low dose oral contraceptives: a cross-over study. Thromb Haemost. 2000;84(1):4-8.

24. Vandenbroucke JP, et al. Oral contraceptives and the risk of venous thrombosis. N Engl J Med. 2001; 344(20):1527-1535.

25. Abdollahi M, Cushman M, Rosendaal FR. Obesity: risk of venous thrombosis and the interaction with coagulation factor levels and oral contraceptive use. Thromb Haemost. 2003;89(3):493-498.

26. Ayer JG, Song C, Steinbeck K, Celermajer DS, Ben Freedman S. Increased tissue factor activity in monocytes from obese young adults. Clin Exp Pharmacol Physiol. 2010;37(11):1049-1054.

27. Khorana AA. Venous thromboembolism and prognosis in cancer. Thromb Res. 2010;125(6):490-493.

28. Caine GJ, Stonelake PS, Lip GY, Kehoe ST. The hypercoagulable state of malignancy: pathogenesis and current debate. Neoplasia. 2002;4(6):465-473.

29. Allman-Farinelli MA. Obesity and venous thrombosis a review. Semin Thromb Hemost. 2011;37(8):903-907.

30. Noble S, Pasi J. Epidemiology and pathophysiology of cancer-associated thrombosis. Br J Cancer. 2010;102(suppl 1):S2-S9.

31. Khorana AA, Kuderer NM, Culakova E, Lyman $\mathrm{GH}$, Francis CW. Development and validation of a predictive model for chemotherapy-associated thrombosis. Blood. 2008;111(10):4902-4907.

32. Ay C, et al. Prediction of venous thromboembolism in cancer patients. Blood. 2010;116(24):5377-5382.

33. Furie B, Furie BC. Mechanisms of thrombus formation. NEngl J Med. 2008;359(9):938-949.

34. Lippi G, Franchini M, Targher G. Arterial thrombus formation in cardiovascular disease. Nat Rev Cardiol. 2011;8(9):502-512.

35. Jackson SP. Arterial thrombosis-insidious, unpredictable and deadly. Nat Med. 2011;17(11):1423-1436.

36. Wakefield TW, Myers DD, Henke PK. Mechanisms of venous thrombosis and resolution. Arterioscler Thromb Vasc Biol. 2008;28(3):387-391.

37. Undas A, Ariëns RA. Fibrin clot structure and function: a role in the pathophysiology of arterial and venous thromboembolic diseases. Arterioscler Thromb Vasc Biol. 2011;31(12):e88-e99.

38. Wolberg AS. Plasma and cellular contributions to fibrin network formation, structure, and stability. Haemophilia. 2010;16(suppl 3):7-12.

39. Mackman N. Role of tissue factor in hemostasis, thrombosis, and vascular development. Arterioscler Thromb Vasc Biol. 2004;24(6):1015-1022.

40. Mackman N, Tilley RE, Key NS. Role of the extrinsic pathway of blood coagulation in hemostasis and thrombosis. Arterioscler Thromb Vasc Biol. 2007; 27(8):1687-1693

41. Mann KG, Butenas S, Brummel K. The dynamics of thrombin formation. Arterioscler Thromb Vasc Biol. 2003;23(1):17-25

42. Gailani D, Renné T. The intrinsic pathway of coagulation: a target for threating thromboembolic disease? J Thromb Haemost. 2007;5(6):1106-1112.

43. Owens AP 3rd, Mackman N. Microparticles in hemostasis and thrombosis. Circ Res. 2011; 108(10):1284-1297.

44. Morel O, Jesel L, Freyssinet JM, Toti F. Cellular mechanisms underlying the formation of circulating microparticles. Arterioscler Thromb Vasc Biol. 2011; 31(1):15-26.

45. Burnier L, Fontana P, Kwak BR, Angelillo-Scherrer A. Cell-derived microparticles in haemostasis and vascular medicine. Thromb Haemost. 2009; 101(3):439-451.

46. Kannemeier C, et al. Extracellular RNA constitutes a natural procoagulant cofactor in blood coagulation. Proc Natl Acad Sci U S A. 2007;104(15):6388-6393.

47. Smith SA, Mutch NJ, Baskar D, Rohloff P, Docampo R, Morrissey JH. Polyphosphate modulates blood coagulation and fibrinolysis. Proc Natl Acad Sci US A. 2006;103(4):903-908.

48. Müller F, et al. Platelet polyphosphates are proinflammatory and procoagulant mediators in vivo. Cell. 2009;139(6):1143-1156.

49. Smith SA, et al. Polyphosphate exerts differential effects on blood clotting, depending on polymer size. Blood. 2010;116(20):4353-4359.

50. Mackman N. Tissue-specific hemostasis in mice. Arterioscler Thromb Vasc Biol. 2005;25(11):2273-2281.

51. Broze GJ Jr. Tissue factor pathway inhibitor. Thromb Haemost. 1995;74(1):90-93.

52. Bauer KA, Rosenberg RD. Role of antithrombin III as a regulator of in vivo coagulation. Semin Hematol. 1991;28(1):10-18.

53. Esmon CT. The regulation of natural anticoagulant pathways. Science. 1987;235(4794):1348-1352.

54. Esmon CT. The protein C pathway. Chest. 2003; 124(3 suppl):26S-32S.

55. Rosenberg RD, Aird WC. Vascular-bed-specific hemostasis and hypercoagulable states. $N$ Engl J Med. 1999;340(20):1555-1564.

56. Plow EF, Hoover-Plow J. The functions of plasminogen in cardiovascular disease. Trends Cardiovasc Med. 2004;14(5):180-186.

57. Fay WP. Plasminogen activator inhibitor 1, fibrin, and the vascular response to injury. Trends Cardiovasc Med. 2004;14(5):196-202.

58. Kearon C, et al. Antithrombotic therapy for venous thromboembolic disease: American College of Chest Physicians Evidence-Based Clinical Practice Guidelines (8th Edition). Chest. 2008; 133 (6 suppl):454S-545S

59. Key NS, Kasthuri RS. Current treatment of venous thromboembolism. Arterioscler Thromb Vasc Biol. 2010;30(3):372-375.

60. Barritt DW, Jordan SC. Anticoagulant drugs in the treatment of pulmonary embolism. A controlled trial. Lancet. 1960;1(7138):1309-1312.

61. Eikelboom JW, Weitz JI. New anticoagulants. Circulation. 2010;121(13):1523-1532.

62. Soff GA. A new generation of oral direct anticoagulants. Arterioscler Thromb Vasc Biol. 2012;32(3):569-574.

63. Perzborn E, Roehrig S, Straub A, Kubitza D, Mueck W, Laux V. Rivaroxaban: a new oral factor Xa inhibitor. Arterioscler Thromb Vasc Biol. 2010;30(3):376-381.

64. Eisert WG, Hauel N, Stangier J, Wienen W, Clemens A, van Ryn J. Dabigatran: an oral novel potent reversible nonpeptide inhibitor of thrombin. Arterioscler Thromb Vasc Biol. 2010;30(10):1885-1889.

65. Turpie AG, et al. Rivaroxaban for the prevention of venous thromboembolism after hip or knee arthroplasty. Pooled analysis of four studies. Thromb Haemost. 2011;105(3):444-453.

66. Virchow RLK. Gesammelte Abhandlungen zur wissenschaftlichen Medicin. Frankfurt, Germany: Von Meidinger \& Sohn; 1856.

67. Cockett FB, Thomas ML. The iliac compression syndrome. Br J Surg. 1965;52(10):816-821.

68. Moudgill N, Hager E, Gonsalves C, Larson R, Lombardi J, DiMuzio P. May-Thurner syndrome: case report and review of the literature involving modern endovascular therapy. Vascular. 2009;17(6):330-335.

69. Brill A, et al. von Willebrand factor-mediated platelet adhesion is critical for deep vein thrombosis in mouse models. Blood. 2011;117(4):1400-1407.

70. von Bruhl M-L, et al. Monocytes, neutrophils, and platelets cooperate to initiate and propagate venous thrombosis in mice in vivo. J Exp Med. 2012; 209(4):819-835.

71. Diaz JA, et al. Critical review of mouse models of venous thrombosis. Arterioscler Thromb Vasc Biol. 2012;32(3):556-562.

72. McEver RP, Cummings RD. Perspectives series: cell adhesion in vascular biology. Role of PSGL-1 binding to selectins in leukocyte recruitment. JClin Invest. 1997;100(3):485-491.

73. Ruggeri ZM. The role of von Willebrand factor in thrombus formation. Thromb Res. 2007; 120(suppl 1):S5-S9.

74. Bovill EG, van der Vliet A. Venous valvular stasisassociated hypoxia and thrombosis: what is the link? Annu Rev Physiol. 2011;73:527-545.

75. Watson SP. Platelet activation by extracellular matrix proteins in haemostasis and thrombosis. Curr Pharm Des. 2009;15(12):1358-1372.

76. Esmon CT, Esmon NL. The link between vascular features and thrombosis. Annu Rev Physiol. 2011; 73:503-514

77. Atkinson B, Dwyer K, Enjyoji K, Robson SC. Ectonucleotidases of the CD39/NTPDase family modulate platelet activation and thrombus formation: Potential as therapeutic targets. Blood Cells Mol Dis. 2006;36(2):217-222.

78. Marcus AJ, et al. The endothelial cell ecto-ADPase responsible for inhibition of platelet function is CD39. J Clin Invest. 1997;99(6):1351-1360.

79. Moore KL, Andreoli SP, Esmon NL, Esmon CT, Bang NU. Endotoxin enhances tissue factor and suppresses thrombomodulin expression of human vascular endothelium in vitro. J Clin Invest. 1987; 79(1):124-130.

80. Ley K, Laudanna C, Cybulsky MI, Nourshargh S. Getting to the site of inflammation: the leukocyte adhesion cascade updated. Nat Rev Immunol. 2007; 7(9):678-689.

81. Williams MR, Azcutia V, Newton G, Alcaide P, Lus- 
cinskas FW. Emerging mechanisms of neutrophil recruitment across the endothelium. Trends Immunol. 2011;32(10):461-469.

82. Pinsky DJ, et al. Hypoxia-induced exocytosis of endothelial cell Weibel-Palade bodies. A mechanism for rapid neutrophil recruitment after cardiac preservation. J Clin Invest. 1996;97(2):493-500.

83. Hamer JD, Malone PC, Silver IA. The PO2 in venous valve pockets: its possible bearing on thrombogenesis. BrJ Surg. 1981;68(3):166-170.

84. Liu GC, Ferris EJ, Reifsteck JR, Baker ME. Effect of anatomic variations on deep venous thrombosis of the lower extremity. Am J Roentgenol. 1986 146(4):845-848.

85. Brooks EG, et al. Valves of the deep venous system: an overlooked risk factor. Blood. 2009;114(6):1276-1279.

86. Tesselaar ME, Romijn FP, Van Der Linden IK, Prins FA, Bertina RM, Osanto S. Microparticle-associated tissue factor activity: a link between cancer and thrombosis? J Thromb Haemost. 2007:5(3):520-527.

87. Tesselaar ME, Romijn FP, van der Linden IK, Bertina RM, Osanto S. Microparticle-associated tissue factor activity in cancer patients with and without thrombosis. J Thromb Haemost. 2009;7(8):1421-1423.

88. Zwicker JI, et al. Tumor-derived tissue factorbearing microparticles are associated with venous thromboembolic events in malignancy. Clin Cancer Res. 2009;15(22):6830-6840.

89. Manly DA, et al. Increased microparticle tissue factor activity in cancer patients with venous thromboembolism. Thromb Res. 2010;125(6):511-512.

90 . Yu JL, et al. Oncogenic events regulate tissue factor expression in colorectal cancer cells: implications for tumor progression and angiogenesis. Blood. 2005;105(4):1734-1741.

91. Davila M, et al. Tissue factor-bearing microparticles derived from tumor cells: impact on coagulation activation. J Thromb Haemost. 2008;6(9):1517-1524.

92. Thomas GM, Panicot-Dubois L, Lacroix R, Dignat-George F, Lombardo D, Dubois C. Cancer cell-derived microparticles bearing P-selectin glycoprotein ligand 1 accelerate thrombus formation in vivo. J Exp Med. 2009;206(9):1913-1927.

93. Khorana AA, et al. Plasma tissue factor may be pre- dictive of venous thromboembolism in pancreatic cancer. J Thromb Haemost. 2008;6(11):1983-1985.

94. Fuchs TA, et al. Extracellular DNA traps promote thrombosis. Proc Natl Acad Sci U S A. 2010; 107(36):15880-15885.

95. Brill A, et al. Neutrophil extracellular traps promote deep vein thrombosis in mice. J Thromb Haemost. 2012;10(1):136-144.

96. Yu FT, Armstrong JK, Tripette J, Meiselman HJ, Cloutier G. A local increase in red blood cell aggregation can trigger deep vein thrombosis: evidence based on quantitative cellular ultrasound imaging. Thromb Haemost. 2011;9(3):481-488.

97. Falati S, et al. Accumulation of tissue factor into developing thrombi in vivo is dependent upon microparticle P-selectin glycoprotein ligand 1 and platelet P-selectin. J Exp Med. 2003;197(11):1585-1598.

98. Chou J, Mackman N, Merrill-Skoloff G, Pedersen B, Furie BC, Furie B. Hematopoietic cell-derived microparticle tissue factor contributes to fibrin formation during thrombus propagation. Blood. 2004; 104(10):3190-3197.

99. Palabrica T, et al. Leukocyte accumulation promoting fibrin deposition is mediated in vivo by P-selectin on adherent platelets. Nature. 1992;359(6398):848-851.

100. Meier TR, et al. Prophylactic P-selectin inhibition with PSI-421 promotes resolution of venous thrombosis without anticoagulation. Thromb Haemost. 2008;99(2):343-351.

101. Myers DD Jr, Henke P, Diaz JA, Wrobleski SK, Hawley AE. Pan-selectin antagonist, GMI-1070 decreases venous thrombosis in a mouse model. ASH Annual Meeting. December 10-13, 2011. Abstract 3273.

102.Massberg S, et al. Reciprocal coupling of coagulation and innate immunity via neutrophil serine proteases. Nat Med. 2010;16(8):887-896.

103.Saha P, et al. Leukocytes and the natural history of deep vein thrombosis: current concepts and future directions. Arterioscler Thromb Vasc Biol. 2011; 31(3):506-512

104. Henke PK, Wakefield T. Thrombus resolution and vein wall injury: dependence on chemokines and leukocytes. Thromb Res. 2009;123(suppl 4):S72-S78. 105. Monetti M, et al. Rosuvastatin displays anti-ath- erothrombotic and anti-inflammatory properties in apoE-deficient mice. Pharmacol Res. 2007; 55(5):441-449.

106. Lacut K, et al. Statins but not fibrates are associated with a reduced risk of venous thromboembolism: a hospital-based case-control study. Fundam Clin Pharmacol. 2004;18(4):477-482.

107. Ramcharan AS, Van Stralen KJ, Snoep JD, MantelTeeuwisse AK, Rosendaal FR, Doggen CJ. HMG$\mathrm{CoA}$ reductase inhibitors, other lipid-lowering medication, antiplatelet therapy, and the risk of venous thrombosis. J Thromb Haemost. 2009;7(4):514-520.

108. Sorensen HT, et al. Arterial cardiovascular events, statins, low-dose aspirin and subsequent risk of venous thromboembolism: a population-based casecontrol study. J Thromb Haemost. 2009;7(4):521-528.

109.Pai M, Evans NS, Shah SJ, Green D, Cook D, Crowther MA. Statins in the prevention of venous thromboembolism: a meta-analysis of observational studies. Thromb Res. 2011;128(5):422-430.

110. Glynn RJ, et al. A randomized trial of rosuvastatin in the prevention of venous thromboembolism. N Engl J Med. 2009;360(18):1851-1861.

111. Ferro D, Basili S, Alessandri C, Mantovani B, Cordova C, Violi F. Simvastatin reduces monocytetissue-factor expression type IIa hypercholesterolaemia. Lancet. 1997;350(9086):1222.

112. Ferro D, Basili S, Alessandri C, Cara D, Violi F. Inhibition of tissue-factor-mediated thrombin generation by simvastatin. Atherosclerosis. 2000;149(1):111-116.

13. Colli S, Eligini S, Lalli M, Camera M, Paoletti R, Tremoli E. Vastatins inhibit tissue factor in cultured human macrophages. A novel mechanism of protection against atherothrombosis. Arterioscler Thromb Vasc Biol. 1997;17(2):265-272.

114. Aikawa M, et al. An HMG-CoA reductase inhibitor, cerivastatin, suppresses growth of macrophages expressing matrix metalloproteinases and tissue factor in vivo and in vitro. Circulation. 2001; 103(2):276-283

115. Owens AP 3rd, et al. Monocyte tissue factor-dependent activation of coagulation in hypercholesterolemic mice and monkeys is inhibited by simvastatin. J Clin Invest. 2012;122(2):558-568. 